University of Nebraska - Lincoln

DigitalCommons@University of Nebraska - Lincoln

1984

\title{
Effects of Excess Arginine With and Without Supplemental Lysine on Performance, Plasma Amino Acid Concentrations and Nitrogen Balance of Young Swine
}

\author{
L. C. Anderson \\ Golden Sun Feeds, Inc.
}

A. J. Lewis

University of Nebraska-Lincoln, alewis2@unl.edu

E. R. Peo, Jr.

University of Nebraska-Lincoln

J. D. Crenshaw

University of Nebraska-Lincoln

Win Butler

McGill University

Follow this and additional works at: https://digitalcommons.unl.edu/animalscifacpub

Part of the Animal Sciences Commons

Anderson, L. C.; Lewis, A. J.; Peo, Jr., E. R.; Crenshaw, J. D.; and Butler, Win, "Effects of Excess Arginine With and Without Supplemental Lysine on Performance, Plasma Amino Acid Concentrations and Nitrogen Balance of Young Swine" (1984). Faculty Papers and Publications in Animal Science. 667.

https://digitalcommons.unl.edu/animalscifacpub/667

This Article is brought to you for free and open access by the Animal Science Department at DigitalCommons@University of Nebraska - Lincoln. It has been accepted for inclusion in Faculty Papers and Publications in Animal Science by an authorized administrator of DigitalCommons@University of Nebraska - Lincoln. 


\title{
EFFECTS OF EXCESS ARGININE WITH AND WITHOUT SUPPLEMENTAL LYSINE ON PERFORMANCE, PLASMA AMINO ACID CONCENTRATIONS AND NITROGEN BALANCE OF YOUNG SWINE ${ }^{1,2}$
}

\author{
L. C. Anderson ${ }^{3}$, A. J. Lewis ${ }^{4,5}$, E. R. Peo, Jr. ${ }^{4}$ and J. D. Crenshaw ${ }^{4}$ \\ University of Nebraska, \\ Lincoln 68583
}

\begin{abstract}
Summary
Three experiments were conducted to determine the effects of excess arginine on performance, plasma amino acid levels and $\mathrm{N}$ balance of young pigs (initial weights $6.9,7.0$ and $10.3 \mathrm{~kg}$, respectively). In a $28-\mathrm{d}$ growth trial, various amounts of arginine ( 0 to $1.6 \%$ ) were added to a conventional starter diet. Addition of arginine decreased $(P<.01)$ average daily feed intake (ADFI) and gain (ADG), but had no effect on feed efficiency (G/F). Plasma urea, arginine and ornithine concentrations were elevated $(\mathrm{P}<.001)$ by the increasing dietary arginine levels at $\mathrm{d} 14$ and 28 . Plasma histidine levels were reduced $(\mathrm{P}<.01)$ at $\mathrm{d} 28$. Plasma lysine levels exhibited a cubic response $(\mathrm{P}<.05)$ at $\mathrm{d} 14$, but were not affected by excess arginine at $d 28$. In a second growth trial ADFI and ADG were decreased $(P<.05)$, but $\mathrm{G} / \mathrm{F}$ was not affected by the addition of $1.6 \%$ dietary arginine. Lysine supplementation $(0$, .15 or $.30 \%)$ increased performance in the absence of excess arginine, but the main effect of lysine was not significant for any performance criteria. As in the first experiment, plasma concentrations of urea, arginine and ornithine were increased $(P<.001)$ by the addition of arginine. Plasma histidine was not affected by either arginine or lysine. Plasma lysine levels
\end{abstract}

\footnotetext{
${ }^{1}$ Published as Paper No. 7097, Journal Series, Nebraska Agr. Exp. Sta. Research reported was conducted under Project 13-052.

${ }^{2}$ The technical assistance of Mary B. Barnes, Roy L. Carlson and Diana J. Smith is gratefully acknowledged.

${ }^{3}$ Current Address: Golden Sun Feeds, Inc., Grinnell, IA 50112.

${ }^{4}$ Dept. of Anim. Sci.

${ }^{5}$ To whom reprint requests should be addressed.

Received March 7, 1983.

Accepted July 18, 1983 .
}

were reduced $(\mathrm{P}<.001)$ by dietary arginine and increased $(\mathrm{P}<.001)$ by lysine. In a $\mathrm{N}$ balance experiment, addition of $1.6 \%$ dietary arginine increased $\mathrm{N}$ digestibility, but decreased apparent biological value. Nitrogen balance was not affected by added arginine. Lysine addition did not improve any of these three indices of $\mathrm{N}$ utilization. The inability of lysine supplementation to alleviate any of the adverse effects of excess arginine in young swine indicates that the reduced performance is caused by a generalized amino acid imbalance, and not by a specific interference with lysine utilization in the manner of a classical arginine-lysine antagonism.

(Key Words: Swine, Arginine, Lysine, Weight Gain, Plasma Amino Acids, Nitrogen Balance.)

\section{Introduction}

Typical swine diets based on corn or sorghum grain and soybean meal contain arginine in amounts that far exceed the pig's requirement (NRC, 1979). In chicks, high levels of lysine interfere with arginine utilization (Snetsinger and Scott, 1961; Jones, 1964; Boorman and Fisher, 1966; D'Mello and Lewis, 1970), and there is some evidence that the antagonism is reciprocal (O'Dell and Savage, 1966). Consequently, there has been interest recently in the possibility that the high arginine content of swine diets may interfere with lysine utilization (Harmon, 1980; Baker, 1982).

Buraczewski et al. (1970) found that when they infused relatively large amounts of crystalline arginine or lysine into the small intestine of a pig fitted with reentrant cannulae, high concentrations of one amino acid lowered the absorption of the other. In contrast, recent experiments in which the arginine content of growing-finishing swine diets has been reduced by changing the feedstuff composition (primar369

JOURNAL OF ANIMAL SCIENCE, Vol. 58, No. 2, 1984 
ily replacing some plant protein sources with animal sources) have been relatively unsuccessful in improving performance (Miller et al., 1981; Anderson et al., 1984).

Studies in which dietary arginine content is reduced by changing feedstuffs suffer from the limitation that other amino acid contents are also altered. This problem can be avoided by the use of crystalline amino acids, but there are differences in the absorption of crystalline amino acids and the amino acids from intact proteins (Matthews, 1975a,b). Recent experiments with young swine (Easter and Baker, 1977; Southern and Baker, 1982; Hagemeier et al., 1983) have demonstrated that the addition of crystalline arginine to diets for young swine can reduce performance.

The purpose of the present research was to determine the effects of both small and large additions of crystalline arginine to diets of young pigs on performance, plasma amino acid concentrations and $\mathrm{N}$ balance. An additional goal was to test whether the reduced performance induced by excess arginine could be alleviated by supplemental lysine.

\section{Materials and Methods}

General. Three experiments were conducted utilizing a total of 228 pigs, weaned at 3 to 4 wk of age. In each experiment the dietary treatments were formulated from a basal starter diet (table 1), which was designed to meet the nutrient requirements of 5 to $10 \mathrm{~kg}$ pigs (NRC, 1979). Treatments were created by adding L-arginine free base and(or) L-lysine $\cdot \mathrm{HCl}$ to the basal diet at the expense of corn.

Exp. 1. Ninety-six crossbred pigs were weaned at 3 to 4 wk of age and were fed a $22 \%$ protein prestarter diet during a 6-d acclimation period. They were then allotted to six treatment groups with four pens/treatment and four pigs (two gilts and two barrows)/pen in a randomized complete block design. Initial weight (avg 6.9 $\mathrm{kg}$ ) was used as the blocking criterion. The dietary treatments consisted of the basal diet with $0, .1, .2, .4, .8$ or $1.6 \%$ added arginine.

Pigs were housed in an environmentally controlled nursery, which contained $1.8 \times$ $1.8 \mathrm{~m}$ pens with partially slatted floors. They were allowed ad libitum access to feed and

TABLE 1. COMPOSITION OF BASAL DIET ${ }^{\mathrm{a}}$

\begin{tabular}{lr}
\hline Ingredient & $\%$ \\
\hline Corn, ground (IFN 4-02-935) & 55.51 \\
Soybean meal (44\% CP; IFN 5-04-604) & 27.33 \\
Oats (IFN 4-03-309) & 10.00 \\
Tallow (IFN 4-07-880) & 3.00 \\
Dicalcium phosphate (IFN 6-01-080) & 1.87 \\
Limestone (IFN 6-02-632) & .69 \\
Salt (IFN 6-04-151) & .50 \\
Trace mineral mixb & .05 \\
Selenium premixc & .05 \\
Vitamin premix + carbadox d & 1.00 \\
Total & 100.00 \\
Analysis, \% & Exp. \\
Protein & 17.74 \\
Ca & .80 \\
P & .74 \\
Arginine & 1.11 \\
Lysine & .89 \\
\hline
\end{tabular}

an Exp. 1, diets contained $0, .1, .2, .4, .8$ or 1.6\% added arginine (as L-arginine free base). In Exp. 2 and 3 , diets contained 0 or $1.6 \%$ added arginine (as L-arginine free base) and $0, .15$ or .30\% lysine (as L-lysine. $\mathrm{HCI}$, $78 \%$ lysine). Additions of amino acids were made at the expense of corn.

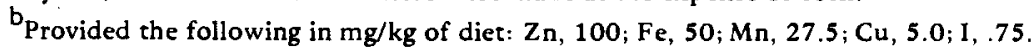

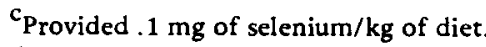

${ }^{d}$ Provided the following per $\mathrm{kg}$ of diet: vitamin A, 5,500 IU; vitamin $\mathrm{D}_{3}, 440 \mathrm{IU}$; vitamin E, 22 IU; riboflavin, $2.9 \mathrm{mg}$; d-pantothenic acid, $22 \mathrm{mg}$; niacin, $22 \mathrm{mg}$; choline chloride, $220 \mathrm{mg}$; vitamin $\mathrm{B}_{12}, 22 \mu \mathrm{g}$; $\mathrm{mena}$ dione sodium bisulfate, $2.2 \mathrm{mg}$ and carbadox, $55 \mathrm{mg}$. 
water during the $28-\mathrm{d}$ experiment. Feed intakes and pig weights were recorded weekly.

On d 14 and 28 of the experiment a blood sample was obtained from each pig by puncture of the anterior vena cava or an adjoining vein. Samples were collected in $10-\mathrm{ml}$ evacuated tubes containing sodium heparin. Plasma was separated by centrifugation at $1,116 \times \mathrm{g}$ for 15 min. Individual plasma samples from each pig were analyzed for urea using the automated procedure described by Marsh et al. (1965). One milliliter of plasma from each pig was pooled by pen to make a composite sample for each pen. The pooled plasma samples were deproteinized using sulfosalicylic acid (30 $\mathrm{mg} / \mathrm{ml}$ of plasma) according to the method of Perry and Hansen (1969). Deproteinized plasma was analyzed for arginine, histidine, lysine and ornithine using ion-exchange separation (Blackburn, 1978) and fluorimetric detection (Benson and Hare, 1975).

Data were analyzed as a randomized complete block design utilizing the Statistical Analysis System (SAS, 1979). Single degree-of-freedom orthogonal polynomials were calculated using coefficients appropriate for the unequally spaced arginine levels employed.

Exp. 2. After weaning at $4 \mathrm{wk}$ of age, 96 crossbred pigs were fed a $22 \%$ protein prestarter diet for 4 to $7 \mathrm{~d}$. They were then allotted to six treatments in a randomized complete block design in a manner similar to that described for Exp. 1. The average initial weight was $7.0 \mathrm{~kg}$. Dietary treatments were arginine added at 0 or $1.6 \%$ of the diet and lysine added at $0, .15$ or $.30 \%$ of the diet in a $2 \times 3$ factorial plan.

Animal housing, management, data collection and sample analysis were identical to Exp. 1 except that pigs were bled only once (on d 28).

Data were analyzed as a randomized complete block with a factorial arrangement of treatments.

Exp. 3. Thirty-six crossbred barrows, with an initial weight of $10.3 \mathrm{~kg}$, were used to determine $\mathrm{N}$ utilization and balance of young pigs fed the six diets used in Exp. 2. The barrows were allotted to three groups of 12 pigs; each group (block) containing two pigs fed each dietary treatment.

Pigs were housed in an environmentally controlled room containing $1.5 \times 1 \mathrm{~m}$ pens and circular metabolism crates. Each group of pigs was first assigned to a preliminary period in which they were individually fed the experimental diets in the pens for $5 \mathrm{~d}$. Pigs were then moved to metabolism crates. After a 2-d adjustment period in the crates, urine, feces and orts were collected daily for $5 \mathrm{~d}$. Diets were offered ad libitum at all times and the daily intake of each pig was recorded.

Urine was collected by allowing it to flow down into a vessel containing $50 \mathrm{ml}$ of a $10 \%$ $(\mathrm{v} / \mathrm{v})$ solution of technical grade concentrated $\mathrm{HCl}$. Daily collections were measured, mixed well, sampled ( $2 \%$ of daily total) and stored at $-20 \mathrm{C}$ until analyzed. Total feces and orts collections were made daily and were also stored at $-20 \mathrm{C}$.

Feces and orts were dried at $50 \mathrm{C}$ for $72 \mathrm{~h}$. After allowing them to equilibrate to room conditions, the entire dried samples were ground through a 4-mm screen in a Wiley mill. Subsamples were then reground in a laboratory micromill. The $\mathrm{N}$ contents of feed, orts, feces and urine were determined by a Kjeldahl procedure similar to that described by the AOAC (1980). Standard equations (Lassiter and Edwards, 1982) were used to compute the various indices of $\mathrm{N}$ utilization (table 6 ).

Statistical analyses were similar to those described for Exp. 2.

\section{Results and Discussion}

Exp. 1. The performance data are presented in table 2 . Addition of increasing amounts ( 0 to $1.6 \%$ ) of crystalline arginine to the basal diet $(1.11 \%$ arginine $)$ resulted in a linear $(\mathrm{P}<.01)$ decrease in average daily feed intake (ADFI) and gain (ADG), but did not affect ( $P>.08)$ feed efficiency $(G / F)$. These results are similar to those of Southern and Baker (1982), who found that additions of $.67,1.33$ or $2.00 \%$ arginine to a basal diet (calculated to contain $1.27 \%$ arginine) resulted in a linear depression in ADFI and ADG of $7.5 \mathrm{~kg}$ pigs, but did not alter $\mathrm{G} / \mathrm{F}$.

In other research, Easter and Baker (1977) reported that the addition of $.5,1.0$ or $1.5 \%$ arginine depressed ADFI, ADG and G/F of $9.1-\mathrm{kg}$ pigs fed diets containing 12 or $26 \%$ crude protein, but not pigs fed diets with $19 \%$ crude protein. Hagemeier et al. (1983) found that additions of .35 or $69 \%$ arginine to diets of $8.0-\mathrm{kg}$ pigs had little or no effect on ADFI and did not affect ADG. There was, however, a linear reduction in $G / F$ in one experiment when arginine was added to a diet that was marginal in lysine.

Based on the research reported herein and that of others (Easter and Baker, 1977; Southern and Baker, 1982; Hagemeier et al., 1983), it 
TABLE 2. PERFORMANCE OF YOUNG SWINE FED VARIOUS LEVELS OF EXCESS ARGININE $($ EXP. 1)

\begin{tabular}{|c|c|c|c|c|c|c|c|}
\hline $\begin{array}{l}\text { Treatment: } \\
\text { Diet type: }\end{array}$ & $\begin{array}{l}1 \\
\text { Basal } \\
(B)^{b}\end{array}$ & $\begin{array}{l}2 \\
\mathrm{~B}+ \\
.1 \% \mathrm{arg}\end{array}$ & $\begin{array}{l}3 \\
\mathrm{~B}+ \\
.2 \% \mathrm{arg}\end{array}$ & $\begin{array}{l}4 \\
\mathrm{~B}+ \\
.4 \% \mathrm{arg}\end{array}$ & $\begin{array}{l}5 \\
\mathrm{~B}+ \\
.8 \% \text { arg }\end{array}$ & $\begin{array}{l}6 \\
\mathrm{~B}+ \\
1.6 \% \mathrm{arg}\end{array}$ & $\mathrm{CV}^{\mathrm{C}}$ \\
\hline $\begin{array}{l}\text { Feed intake, g/dd } \\
\text { Weight gain, g/dd } \\
\text { Gain/feed }\end{array}$ & $\begin{array}{l}562 \\
312 \\
\quad 555\end{array}$ & $\begin{array}{rr}585 & \\
343 & \\
& .589\end{array}$ & $\begin{array}{r}552 \\
324 \\
\quad .585\end{array}$ & $\begin{array}{l}\begin{array}{l}498 \\
300 \\
.606\end{array}\end{array}$ & $\begin{array}{r}516 \\
278 \\
\quad .540\end{array}$ & $\begin{array}{l}470 \\
268 \\
\quad .573\end{array}$ & $\begin{array}{r}10.24 \\
11.99 \\
9.27\end{array}$ \\
\hline
\end{tabular}

${ }^{2}$ Values represent the mean of four replicates of four pigs; average initial weight was $6.9 \mathrm{~kg}$; 28 -d experiment.

$\mathrm{b}_{\text {The basal diet contained } 1.11 \% \text { arginine. }}$

${ }^{c}$ Coefficient of variation, $\%$.

$d_{\text {Linear effect }}(P<.01)$

seems that, although the addition of crystalline arginine to the diets of baby pigs usually reduces $A D F I$ and ADG, the reductions are small unless relatively large amounts $(\geqslant .4 \%)$ of arginine are added.

Plasma urea and amino acid concentrations are presented in table 3 . Addition of arginine resulted in linear $(P<.001)$ increases in urea, arginine and ornithine at both bleeding periods. Mitchell et al. (1968; and many others) have reported than when young pigs are fed supraoptimal dietary levels of an amino acid, there is an accumulation of that amino acid in the plasma. Thus, the increase in the plasma arginine is consistent with previous findings. The increases in plasma urea and ornithine levels presumably reflect catabolism of the excess arginine via the urea cycle. Southern and Baker (1982) and Hagemeier et al. (1983) also observed significant increases in plasma arginine and ornithine when dietary arginine was increased. Neither group measured plasma urea concentrations.

Plasma histidine levels were not affected by dietary arginine at the first bleeding, but at the second bleeding there was a small but significant $(\mathrm{P}<.01)$ reduction in plasma histidine as dietary arginine increased. Similar small decreases in plasma histidine were recorded by both Southern and Baker (1982) and Hagemeier et al. (1983).

In the present experiments, plasma lysine levels exhibited a cubic response $(\mathrm{P}<.05)$ to dietary arginine at the first bleeding; the overall tendency being a decrease (linear component $\mathrm{P}<.08$ ). There were, however, no significant differences in plasma lysine concentrations at the second bleeding. Previous reports have also described changes in plasma lysine. Southern and Baker (1982) consistently found a depression in plasma lysine (as well as other amino acids) when young pigs were fed excess dietary arginine. Hagemeier et al. (1983) observed a depression in plasma lysine when arginine was added to a diet containing adequate lysine $(1.26 \%)$, but not when it was added to diets marginal in lysine (1.03 and $.92 \%)$. Thus, the various reports are in agreement that excess arginine can affect plasma lysine concentration. But, other amino acids are also affected (e.g., histidine in the present experiment) and consequently, it is not clear from these data whether the changes in plasma lysine reflect a specific arginine-lysine antagonism or whether they are associated with a more general type of amino acid imbalance.

Exp. 2. Addition of $1.6 \%$ crystalline arginine to a basal diet containing $1.09 \%$ arginine reduced $(\mathrm{P}<.05)$ ADFI and ADG of young pigs (table 4). The excess arginine did not affect $(P>.10) G / F$. The influence of dietary arginine was consistent regardless of the level of lysine added. These data are also consistent with the results of Exp. 1.

The main effect of lysine was not significant $(P>.10)$ for any of the performance criteria, although there was a trend $(\mathrm{P}<.06)$ toward a linear effect of lysine on $G / F$. This indicates that when considered across both dietary arginine levels, supplemental lysine had little effect on performance. Although there was no arginine $x$ lysine interaction $(P>.10)$ for any of the traits, there was a consistent increase in ADFI, ADG and G/F when lysine was added to the basal diet without additional arginine. A response to supplemental lysine when the diet 
TABLE 3. CONCENTRATIONS (MG/DL) OF UREA AND AMINO ACIDS IN PLASMA OF YOUNG SWINE FED VARIOUS LEVELS OF ARGININE (EXP. 1) ${ }^{a}$

\begin{tabular}{|c|c|c|c|c|c|c|c|c|}
\hline Metabolite & $\begin{array}{l}\text { Treatment: } \\
\text { Diet type: } \\
\text { Time }\end{array}$ & $\begin{array}{l}1 \\
\text { Basal } \\
(\mathrm{B})^{b}\end{array}$ & $\begin{array}{l}2 \\
\mathrm{~B}+ \\
.1 \% \text { arg }\end{array}$ & $\begin{array}{l}3 \\
\mathrm{~B}+ \\
.2 \% \text { arg }\end{array}$ & $\begin{array}{l}4 \\
\mathrm{~B}+ \\
.4 \% \text { arg }\end{array}$ & $\begin{array}{l}5 \\
\mathrm{~B}+ \\
.8 \% \text { arg }\end{array}$ & $\begin{array}{l}6 \\
\mathrm{~B}+ \\
1.6 \% \mathrm{arg}\end{array}$ & $\mathrm{CV}^{\mathrm{c}}$ \\
\hline \multicolumn{9}{|l|}{ Urea } \\
\hline & $\begin{array}{l}14 \mathrm{~d}^{\mathrm{d}} \\
28 \mathrm{~d}^{\mathrm{d}}\end{array}$ & $\begin{array}{l}28.57 \\
29.12\end{array}$ & $\begin{array}{l}28.87 \\
31.36\end{array}$ & $\begin{array}{l}28.68 \\
30.61\end{array}$ & $\begin{array}{l}33.72 \\
34.86\end{array}$ & $\begin{array}{l}36.38 \\
35.20\end{array}$ & $\begin{array}{l}41.96 \\
43.06\end{array}$ & $\begin{array}{l}6.70 \\
9.98\end{array}$ \\
\hline \multicolumn{9}{|l|}{ Arginine } \\
\hline & $\begin{array}{l}14 \mathrm{~d}^{\mathrm{d}} \\
28 \mathrm{~d}^{\mathrm{d}}\end{array}$ & $\begin{array}{l}4.41 \\
4.72\end{array}$ & $\begin{array}{l}5.13 \\
5.63\end{array}$ & $\begin{array}{l}4.48 \\
5.78\end{array}$ & $\begin{array}{l}4.73 \\
6.62\end{array}$ & $\begin{array}{l}5.78 \\
6.84\end{array}$ & $\begin{array}{r}8.21 \\
10.65\end{array}$ & $\begin{array}{l}16.27 \\
16.38\end{array}$ \\
\hline Histidine & $\begin{array}{l}14 d^{2} \\
28 d^{e}\end{array}$ & $\begin{array}{l}2.23 \\
2.80\end{array}$ & $\begin{array}{l}2.30 \\
2.80\end{array}$ & $\begin{array}{l}2.00 \\
2.62\end{array}$ & $\begin{array}{l}1.89 \\
2.79\end{array}$ & $\begin{array}{l}2.54 \\
2.18\end{array}$ & $\begin{array}{l}2.02 \\
2.28\end{array}$ & $\begin{array}{l}20.37 \\
12.92\end{array}$ \\
\hline Lysine & $\begin{array}{l}14 \mathrm{df}^{\mathrm{f}} \\
28 \mathrm{~d}\end{array}$ & $\begin{array}{l}2.55 \\
2.32\end{array}$ & $\begin{array}{l}2.18 \\
2.80\end{array}$ & $\begin{array}{l}1.76 \\
2.74\end{array}$ & $\begin{array}{l}1.95 \\
2.37\end{array}$ & $\begin{array}{l}2.06 \\
2.47\end{array}$ & $\begin{array}{l}1.83 \\
2.37\end{array}$ & $\begin{array}{l}16.82 \\
25.01\end{array}$ \\
\hline Ornithine & $\begin{array}{l}14 \mathrm{~d}^{\mathrm{d}} \\
28 \mathrm{~d}^{\mathrm{d}}\end{array}$ & $\begin{array}{l}2.75 \\
2.46\end{array}$ & $\begin{array}{l}3.27 \\
2.77\end{array}$ & $\begin{array}{l}2.92 \\
3.06\end{array}$ & $\begin{array}{l}3.12 \\
3.49\end{array}$ & $\begin{array}{l}4.44 \\
3.99\end{array}$ & $\begin{array}{l}5.37 \\
5.83\end{array}$ & $\begin{array}{l}18.19 \\
10.89\end{array}$ \\
\hline
\end{tabular}

\footnotetext{
${ }^{a}$ Values represent the mean of four replicates of four pigs for urea, and the mean of four replicates of a pooled sample of plasmas from four pigs for amino acids. The pigs were bled on $\mathrm{d} 14$ and 28 of the experiment.

${ }^{\mathrm{b}}$ The basal diet contained $1.11 \%$ arginine.

${ }^{c}$ Coefficient of variation, $\%$.

$d_{\text {Linear effect }(P<.001)}$.

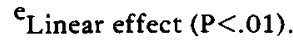

$f_{\text {Cubic effect }}(P<.05)$.
}

contains less than $1 \%$ total lysine has been reported by us previously (Lewis et al., 1980).

It is clear that lysine, at the levels added in this experiment, did not alleviate any of the adverse effects on ADFI or ADG caused by feeding $1.6 \%$ added arginine. Similarly, Southern and Baker (1982) found that neither $.5 \%$ nor $2.5 \%$ supplemental lysine ameliorated the reduced ADFI and ADG caused by the addition of $2.0 \%$ crystalline arginine. Taken together, these data provide strong evidence that any negative effects in young swine caused by large additions of crystalline arginine are due to a general type of amino acid imbalance and not a specific arginine-lysine antagonism.

Addition of excess arginine increased $(P<.001)$ plasma concentrations of urea, arginine and ornithine (table 5). This effect was similar to that observed in Exp. 1. Lysine addition did not alter the plasma levels of these three metabolites and there were no arginine $x$ lysine interactions.

Plasma histidine was not affected $(P>.10)$ by addition of either arginine or lysine. In contrast, plasma lysine concentrations were influenced by both dietary arginine and dietary lysine. As would be expected, adding lysine to the diet resulted in a linear increase $(\mathrm{P}<.001)$ in plasma lysine. The overall effect of adding arginine was to reduce $(\mathrm{P}<.001)$ plasma lysine, but there was an arginine $x$ lysine interaction $(P<.01)$. Although dietary arginine tended to decrease plasma lysine at all levels of dietary lysine, it is clear that the reduction was most pronounced at the highest dietary lysine level. Other researchers have noted somewhat similar effects. Hagemeier et al. (1983) found that plasma lysine was decreased by dietary arginine in pigs fed $1.26 \%$ lysine, but not in pigs fed $1.03 \%$ lysine. They commented that the lack of a reduction in plasma lysine of pigs fed $1.03 \%$ was 'not surprising, because lysine was already at baseline levels.'

Although the changes observed in plasma lysine are suggestive of a specific antagonism between arginine and lysine, this was not borne out by the performance data. In fact, there seems to be little correlation between the ADG data and the changes in plasma lysine. Thus, ADG and plasma lysine appeared to be positively 
TABLE 4. PERFORMANCE OF YOUNG SWINE FED VARIOUS LEVELS OF ARGININE AND LYSINE (EXP. 2) ${ }^{\mathrm{a}}$

\begin{tabular}{|c|c|c|c|c|c|c|}
\hline \multirow[b]{2}{*}{ Criterion } & \multirow{2}{*}{$\begin{array}{l}\text { Level of added } \\
\text { arginine, } \%\end{array}$} & \multicolumn{2}{|c|}{ Level of added lysine, $\% \mathrm{~b}$} & & \multirow{2}{*}{$\begin{array}{l}\text { Avg effect } \\
\text { of arginine }\end{array}$} & \multirow[b]{2}{*}{$\mathrm{CVC}$} \\
\hline & & 0 & .15 & .30 & & \\
\hline $\begin{array}{l}\text { Feed intake, } g / \mathrm{dd}^{\mathrm{d}} \\
\text { Avg effect of lysine }\end{array}$ & $\begin{array}{l}0 \\
1.6\end{array}$ & $\begin{array}{l}645 \\
574 \\
609\end{array}$ & $\begin{array}{l}658 \\
542 \\
600\end{array}$ & $\begin{array}{l}696 \\
\frac{587}{641}\end{array}$ & $\begin{array}{l}667 \\
567\end{array}$ & 14.16 \\
\hline $\begin{array}{l}\text { Weight gain, g/dd } \\
\text { Avg effect of lysine }\end{array}$ & $\begin{array}{l}0 \\
1.6\end{array}$ & $\begin{array}{l}378 \\
\frac{348}{363}\end{array}$ & $\begin{array}{l}400 \\
329 \\
365\end{array}$ & $\begin{array}{l}426 \\
362 \\
394\end{array}$ & $\begin{array}{l}401 \\
347\end{array}$ & 14.09 \\
\hline $\begin{array}{l}\text { Gain/feede } \\
\text { Avg effect of lysine }\end{array}$ & $\begin{array}{l}0 \\
1.6\end{array}$ & $\begin{array}{r}.585 \\
.612 \\
.598\end{array}$ & $\begin{array}{l}.607 \\
.608 \\
.607\end{array}$ & $\begin{array}{r}.614 \\
.615 \\
.615\end{array}$ & $\begin{array}{l}.602 \\
.612\end{array}$ & 2.60 \\
\hline
\end{tabular}

${ }^{a}$ Values represent the mean of four replicates of four pigs; average initial weight was $7.0 \mathrm{~kg}$; 28 -d experiment.

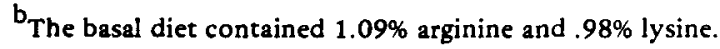

${ }^{c}$ Coefficient of variation, $\%$.

$\mathrm{d}_{\text {Arginine effect }}(\mathrm{P}<.05)$.

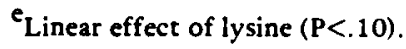

associated in the absence of arginine addition, not significant, the addition of lysine without but there was no such relationship when arginine tended to decrease the plasma concensupplemental arginine was included. Although trations of arginine, histidine and ornithine,

TABLE 5. CONCENTRATIONS (MG/DL) OF UREA AND AMINO ACIDS IN PLASMA OF YOUNG SWINE FED VARIOUS LEVELS OF ARGININE AND LYSINE (EXP. 2)

\begin{tabular}{|c|c|c|c|c|c|c|}
\hline \multirow[b]{2}{*}{ Metabolite } & \multirow{2}{*}{$\begin{array}{l}\text { Level of added } \\
\text { arginine, } \%\end{array}$} & \multicolumn{3}{|c|}{ Level of added lysine, $\% \mathrm{~b}$} & \multirow{2}{*}{$\begin{array}{l}\text { Avg effect } \\
\text { of arginine }\end{array}$} & \multirow[b]{2}{*}{$\mathrm{CV}^{\mathrm{c}}$} \\
\hline & & 0 & .15 & .30 & & \\
\hline $\begin{array}{l}\text { Uread } \\
\text { Avg effect of lysine }\end{array}$ & $\begin{array}{l}0 \\
1.6\end{array}$ & $\begin{array}{l}33.14 \\
47.31 \\
40.22\end{array}$ & $\begin{array}{l}30.50 \\
47.44 \\
38.97\end{array}$ & $\begin{array}{l}30.73 \\
50.67 \\
40.70\end{array}$ & $\begin{array}{l}31.46 \\
48.47\end{array}$ & 11.68 \\
\hline $\begin{array}{l}\text { Arginined } \\
\text { Avg effect of lysine }\end{array}$ & $\begin{array}{l}0 \\
1.6\end{array}$ & $\begin{array}{l}4.86 \\
7.92 \\
6.39\end{array}$ & $\begin{array}{r}4.20 \\
11.06 \\
7.63\end{array}$ & $\begin{array}{l}4.14 \\
9.78 \\
6.96\end{array}$ & $\begin{array}{l}4.40 \\
9.59\end{array}$ & 21.58 \\
\hline $\begin{array}{l}\text { Histidine } \\
\text { Avg effect of lysine }\end{array}$ & $\begin{array}{l}0 \\
1.6\end{array}$ & $\begin{array}{l}2.59 \\
2.21 \\
2.40\end{array}$ & $\begin{array}{l}2.43 \\
2.35 \\
2.39\end{array}$ & $\begin{array}{l}2.36 \\
2.45 \\
2.40\end{array}$ & $\begin{array}{l}2.46 \\
2.34\end{array}$ & 12.23 \\
\hline $\begin{array}{l}\text { Lysine def } \\
\text { Avg effect of lysine }\end{array}$ & $\begin{array}{l}0 \\
1.6\end{array}$ & $\begin{array}{l}3.10 \\
2.09 \\
2.60\end{array}$ & $\begin{array}{l}5.14 \\
4.45 \\
4.79\end{array}$ & $\begin{array}{l}6.87 \\
2.97 \\
4.92\end{array}$ & $\begin{array}{l}5.04 \\
3.17\end{array}$ & 21.50 \\
\hline $\begin{array}{l}\text { Ornithinedf } \\
\text { Avg effect of lysine }\end{array}$ & $\begin{array}{l}0 \\
1.6\end{array}$ & $\begin{array}{l}3.39 \\
6.16 \\
4.78\end{array}$ & $\begin{array}{l}3.09 \\
7.13 \\
5.11\end{array}$ & $\begin{array}{l}2.62 \\
7.25 \\
4.94\end{array}$ & $\begin{array}{l}3.04 \\
6.85\end{array}$ & 10.67 \\
\hline
\end{tabular}

${ }^{a}$ Values represent the mean of four replicates of four pigs for urea, and the mean of four replicates of a pooled sample of plasmas from four pigs for amino acids. The pigs were bled at the end of the 28-d experiment.

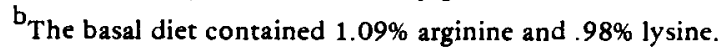

${ }^{c}$ Coefficient of variation, \%.

$\mathrm{d}_{\text {Arginine effect }(}(\mathrm{P}<.001)$.

$e_{\text {Lysine effect }(P<.001) .}$

$f_{\text {Arginine }} X$ lysine interaction $(P<.01)$. 
supporting the concept that lysine was limiting in the basal diet. In the presence of supplemen tal arginine, addition of lysine tended to increase the plasma concentrations of these three amino acids.

Exp. 3. In the $\mathrm{N}$ balance experiment (table 6) there was a linear reduction $(P<.05)$ in ADFI as supplemental lysine was added to the diet. This response was in contrast to that observed in Exp. 2 where supplemental lysine increased feed intake. The reason for the discrepancy is not known; perhaps the shorter experimental period and the fact that the pigs were heavier were involved. Despite the reduction in feed intake there was an increase in lysine intake. The daily intakes of lysine for pigs fed $0, .15$ and $.30 \%$ added lysine were $10.28,11.04$ and 12.13 $\mathrm{g} / \mathrm{d}$, respectively. Arginine addition did not alter $(\mathrm{P}>.10)$ ADFI during the $12-\mathrm{d}$ period that the pigs consumed the diets. Pigs fed diets with added arginine consumed more $(\mathrm{P}<.001) \mathrm{N}$, because of the higher total $\mathrm{N}$ content of the diets.

Fecal $\mathrm{N}$ excretion was similar $(\mathrm{P}>.10)$ for all pigs regardless of arginine or lysine content of the diet. Differences in $\mathrm{N}$ excretion were exhibited in urinary $\mathrm{N}$ levels. Pigs fed diets with added arginine had greater $(\mathrm{P}<.001)$ daily urinary $\mathrm{N}$ than pigs fed the basal diet. The quantity of urinary urea (the major metabolite of $\mathrm{N}$ excretion in swine), is greatly influenced by protein quality and amino acid balance (Brown and Cline, 1974). Evidently, the imbalance created by the excess arginine increased urinary $\mathrm{N}$, but the imbalance was not alleviated by supplemental lysine.

Apparent $\mathrm{N}$ digestibility was higher $(\mathrm{P}<.05)$ in diets containing added arginine. This would be expected if one assumes that the crystalline

TABLE 6. NITROGEN BALANCE OF YOUNG SWINE FED VARIOUS LEVELS OF ARGNINIE AND LYSINE (EXP, 3)

\begin{tabular}{|c|c|c|c|c|c|c|}
\hline \multirow[b]{2}{*}{ Criterion } & \multirow{2}{*}{$\begin{array}{l}\text { Level of added } \\
\text { arginine, } \%\end{array}$} & \multicolumn{3}{|c|}{ Level of added lysine, $\% \mathrm{~b}$} & \multirow{2}{*}{$\begin{array}{l}\text { Avg effect } \\
\text { of arginine }\end{array}$} & \multirow[b]{2}{*}{$\mathrm{CVC}$} \\
\hline & & 0 & .15 & .30 & & \\
\hline $\begin{array}{l}\text { Feed intake, g/dd } \\
\text { Avg effect of lysine }\end{array}$ & $\begin{array}{l}0 \\
1.6\end{array}$ & $\begin{array}{l}1,062.92 \\
1,035.85 \\
1,049.38\end{array}$ & $\begin{array}{l}996.26 \\
958.51 \\
977.38\end{array}$ & $\begin{array}{l}941.56 \\
954.40 \\
947.98\end{array}$ & $\begin{array}{r}1,000.25 \\
982.92\end{array}$ & 10.42 \\
\hline $\begin{array}{l}\text { N intake, } g / d e \\
\text { Avg effect of lysine }\end{array}$ & $\begin{array}{l}0 \\
1.6\end{array}$ & $\begin{array}{l}29.54 \\
33.28 \\
31.41\end{array}$ & $\begin{array}{l}27.88 \\
\frac{31.01}{29.45}\end{array}$ & $\begin{array}{l}26.37 \\
31.46 \\
28.92\end{array}$ & $\begin{array}{l}27.93 \\
31.92\end{array}$ & 10.67 \\
\hline $\begin{array}{l}\text { Fecal } N, g / d \\
\text { Avg effect of lysine }\end{array}$ & $\begin{array}{l}0 \\
1.6\end{array}$ & $\begin{array}{l}4.71 \\
4.78 \\
4.74\end{array}$ & $\begin{array}{l}4.75 \\
4.86 \\
4.80\end{array}$ & $\begin{array}{l}4.59 \\
4.61 \\
4.60\end{array}$ & $\begin{array}{l}4.68 \\
4.75\end{array}$ & 16.44 \\
\hline $\begin{array}{l}\text { Urinary } N, g / d^{e} \\
\text { Avg effect of lysine }\end{array}$ & $\begin{array}{l}0 \\
1.6\end{array}$ & $\begin{array}{r}6.20 \\
10.76 \\
8.48\end{array}$ & $\begin{array}{l}5.67 \\
9.65 \\
7.66\end{array}$ & $\begin{array}{l}6.35 \\
9.93 \\
8.14\end{array}$ & $\begin{array}{r}6.07 \\
10.11\end{array}$ & 23.21 \\
\hline $\begin{array}{l}\text { N digestibility, } \% \mathrm{f} \\
\text { Avg effect of lysine }\end{array}$ & $\begin{array}{l}0 \\
1.6\end{array}$ & $\begin{array}{l}83.79 \\
85.51 \\
84.65\end{array}$ & $\begin{array}{l}83.03 \\
83.94 \\
83.49\end{array}$ & $\begin{array}{l}81.96 \\
84.93 \\
83.45\end{array}$ & $\begin{array}{l}82.93 \\
84.80\end{array}$ & 2.48 \\
\hline $\begin{array}{l}\text { N balance, } g / d^{d} \\
\text { Avg effect of lysine }\end{array}$ & $\begin{array}{l}0 \\
1.6\end{array}$ & $\begin{array}{l}18.63 \\
17.75 \\
18.19\end{array}$ & $\begin{array}{l}17.46 \\
16.50 \\
16.98\end{array}$ & $\begin{array}{l}15.43 \\
16.92 \\
16.18\end{array}$ & $\begin{array}{l}17.17 \\
17.06\end{array}$ & 13.49 \\
\hline $\begin{array}{l}\text { Apparent biological value, \%e } \\
\text { Avg effect of lysine }\end{array}$ & $\begin{array}{l}0 \\
1.6\end{array}$ & $\begin{array}{l}74.95 \\
\frac{62.99}{68.97}\end{array}$ & $\begin{array}{l}75.51 \\
64.01 \\
69.86\end{array}$ & $\begin{array}{l}70.59 \\
63.30 \\
66.95\end{array}$ & $\begin{array}{l}73.75 \\
63.44\end{array}$ & 7.21 \\
\hline
\end{tabular}

\footnotetext{
${ }^{a}$ Values represent the mean of six pigs; average initial weight was $10.3 \mathrm{~kg}$.

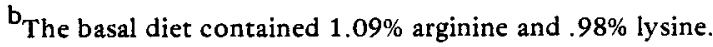

${ }^{c}$ Coefficient of variation, $\%$.

$d_{\text {Linear lysine effect }(P<.05) \text {. }}$

${ }^{\mathrm{e}}$ Arginine effect $(\mathrm{P}<.001)$.

${ }^{f}$ Arginine effect $(P<.05)$.
} 
arginine is completely absorbed. Increasing lysine levels did not affect $\mathrm{N}$ digestibility at either level of arginine. Lysine additions may not have been substantial enough to produce a significant increase in digestibility.

Nitrogen balance was not different $(P>.10)$ between pigs fed diets with high and normal arginine contents. As mentioned previously, fecal $\mathrm{N}$ excretion was similar. The marked difference in urinary $\mathrm{N}$ between pigs fed the different arginine levels was nearly the same as the difference in total $\mathrm{N}$ intake (4.04 vs 3.99 $\mathrm{g} / \mathrm{d}$, respectively). Thus, it seems that the excess arginine was absorbed, but was catabolized to urea and the extra $\mathrm{N}$ was excreted without affecting $\mathrm{N}$ balance. It is significant that ADFI was not different between arginine levels (in contrast to Exp. 1 and 2 where longer feeding periods reduced ADFI). When feed intake differences are absent, the effects on $\mathrm{N}$ balance and, presumably, ADG were essentially eliminated. Harper et al. (1970), in their extensive review, concluded that the negative effects associated with amino acid imbalance are eliminated when the intake of the control and imbalanced diets are equalized. The fact that both ADFI and ADG decreased in Exp. 1 and 2 but $\mathrm{G} / \mathrm{F}$ was not affected supports that conclusion. In contrast, in chicks, where a specific antagonism exists between arginine and lysine, birds fed diets with excess lysine had a lower growth rate than birds fed control diets when ADFI was equalized (Allen et al., 1972). A model of the various mechanisms involved in the arginine-lysine antagonism in chicks has been presented by Austic and Scott (1975). In the present experiment, the similar $\mathrm{N}$ balance values indicate that the excess arginine caused a general type of amino acid imbalance in the experimental diets.

Lysine supplementation decreased $(\mathrm{P}<.05)$ $\mathrm{N}$ balance in a linear fashion. The reduction in ADFI and $N$ intake was responsible for these differences, because fecal and urinary $\mathrm{N}$ excretion rates were similar regardless of the dietary lysine level.

Apparent biological value was lower $(\mathrm{P}<.001)$ in diets that contained added arginine. The greater urinary $\mathrm{N}$ excretion accounted for the decrease in apparent biological value. Lysine additions were ineffective in increasing the biological value of the diets at either level of dietary arginine. It seems that young growing pigs are capable of catabolizing arginine at levels far greater than those found in conven- tional starter diets through normal urea cycle activity, with little or no effect on lysine needs.

Thus, although it is quite evident that the addition of relatively large amounts of crystalline arginine to conventional diets for young pigs reduces ADFI and ADG, these effects are not alleviated by lysine additions. The lack of improvement in $\mathrm{N}$ status of pigs fed excess arginine when lysine was supplemented is further evidence that, although an amino acid imbalance can be created by arginine additions to a normal swine diet, it is not caused by a specific interference with lysine utilization in the manner of a classical arginine-lysine antagonism.

\section{Literature Cited}

Allen, N. K., D. H. Baker, H. M. Scott and H. W. Norton. 1972. Quantitative effect of excess lysine on the ability of arginine to promote chick weight gain. J. Nutr. 102:171.

Anderson, L. C., A. J. Lewis, E. R. Peo, Jr. and J. D. Crenshaw. 1984. Effect of various dietary arginine:lysine ratios on performance, carcass composition and plasma amino acid concentrations of growing-finishing swine. J. Anim. Sci. 58:,

AOAC. 1980. Official Methods of Analysis (13th Ed.). Association of Official Analytical Chemists, Washington, DC.

Austic, R. E. and R. L. Scott. 1975. Involvement of food intake in the lysine-arginine antagonism in chicks. J. Nutr. 105:1122.

Baker, D. H. 1982. Importance of amino acid balance in swine rations. Feedstuffs 54(10): 40 .

Benson, J. R. and P. E. Hare. 1975. O-Phthalaldehyde: Fluorogenic detection of primary amines in the picomole range. Comparison with fluorescamine and ninhydrin. Proc. Natl. Acad. Sci. USA 72:619.

Blackburn, S. 1978. Amino Acid Determination (2nd Ed.). Marcel Dekker Inc., New York.

Boorman, K. N. and H. Fisher. 1966. The argininelysine interaction in the chick. Brit. Poul. Sci. 7:39.

Brown, J. A. and T. R. Cline. 1974. Urea excretion in the pig: An indicator of protein quality and amino acid requirements. J. Nutr. 104:542.

Buraczewski, S., A. G. Chamberlain, F. Horszczaruk and T. Zebrowska. 1970. Lysine and arginine interactions affecting their absorption from the duodenum of the pig. Proc. Nutr. Soc. 29:51A (Abstr.).

D'Mello, J.P.F. and D. Lewis. 1970. Amino acid interactions in chick nutrition. I. The interrelationship between lysine and arginine. Brit. Poul. Sci. 11:299.

Easter, R. A. and D. H. Baker. 1977. Arginine and its relationship to the antibiotic growth response in swine. J. Anim. Sci. 45:108.

Hagemeier, D. L., G. W. Libal and R. C. Wahlstrom. 1983. Effects of excess arginine on swine growth and plasma amino acid levels. J. Anim. Sci. 57:99. 
Harmon, B. G. 1980 . The role of amino acid balance in practical swine rations. Proc. 41st Minnesota Nutr. Conf. p 132.

Harper, A. E., N. J. Benevenga and R. M. Wohlhueter. 1970. Effects of ingestion of disproportionate amounts of amino acids. Physiol. Rev. 50:428.

Jones, J. D. 1964. Lysine-arginine antagonism in the chick. J. Nutr. 84:313.

Lassiter, J. W. and H. M. Edwards, Jr. 1982. Animal Nutrition. Reston Publishing Co., Reston, VA.

Lewis, A. J., E. R. Peo, Jr., B. D. Moser and T. D. Crenshaw. 1980. Lysine requirement of pigs weighing 5 to $15 \mathrm{~kg}$ fed practical diets with and without added fat. J. Anim. Sci. 51:361

Marsh, W. H., B. Fingerhut and H. Miller. 1965. Automated and manual direct methods for the determination of blood urea. Clin. Chem. 11:624.

Matthews, D. M. 1975a. Intestinal absorption of peptides. Physiol. Rev. 55:537.

Matthews, D. M. 1975b. Protein absorption. Bibl. Nutr. Dieta 22:28.

Miller, E. R., J. Skomial, P. K. Ku and M. G. Hogberg. 1981. An evaluation of improving dietary amino acid balance of growing-finishing pigs. J. Anim. Sci. 53 (Suppl. 1):93.
Mitchell, J. R., Jr., D. E. Becker, A. H. Jensen, B. G. Harmon and H. W. Norton. 1968. Determination of amino acid needs of the young pig by nitrogen balance and plasma-free amino acids. J. Anim. Sci. 27:1327.

NRC. 1979. Nutrient Requirements of Domestic Animals, No. 2. Nutrient Requirements of Swine. Eighth Revised Ed. National Academy of SciencesNational Research Council, Washington, DC.

O'Dell, B. L. and J. E. Savage. 1966. Arginine-lysine antagonism in the chick and its relationsbip to dietary cations. J. Nutr. 90:364.

Perry, T. L. and S. Hansen. 1969. Technical pitfalls leading to errors in the quantitation of plasma amino acids. Clin. Chim. Acta 25:53.

SAS. 1979. SAS User's Guide. Statistical Analysis System Institute Inc., Cary, NC.

Snetsinger, D. C. and H. M. Scott. 1961. Efficacy of glycine and arginine in alleviating the stress induced by dietary excesses of single amino acids. Poul. Sci. 40:1675.

Southern, L. L. and D. H. Baker. 1982. Performance and concentration of amino acids in plasma and urine of young pigs fed diets with excesses of either arginine or lysine. J. Anim. Sci. 55:857. 